\title{
ANTIFUNGAL PROPERTIES OF SECONDARY METABOLITES OF AZADIRACHTA INDICA AND LAWSONIA INERMIS - AN IN SILICO STUDY
}

\author{
SIMHADRI VSDNA NAGESH ${ }^{1 *}$, MUNIAPPAN $\mathrm{M}^{2}$, KANNAN $\mathrm{I}^{3}$, VISWANATHAN $\mathrm{S}^{4}$ \\ ${ }^{1}$ Department of Pharmacology, Bharath University, Tagore Medical College and Hospital, Chennai, Tamil Nadu, India. ${ }^{2}$ Department of \\ Pharmacology, Sree Balaji Medical College, and Hospital, Chennai, Tamil Nadu, India. ${ }^{3}$ Department of Microbiology, Tagore Medical \\ College, and Hospital, Chennai, Tamil Nadu, India. ${ }^{4}$ Department of Pharmacology, Meenakshi Medical College, and Hospital, Chennai, \\ Tamil Nadu, India. Email: nageshsai117@tagoremch.com
}

Received: 16 April 2018, Revised and Accepted: 09 May 2018

\section{ABSTRACT}

Objective: This study was aimed to inhibit the sulfite reductase using naturally obtained secondary metabolites of common plants Azadirachta indica and Lawsonia inermis

Methods: The active ingredients of neem and henna were selected and the.sdf files of these were downloaded from PubChem database. Converted the.sdf files to.pdb files with the help of OPENBABEL software which is prerequisite to dock. The three-dimensional structure was incurred from the template of homology of sulfite reductase using MODELLAR software version 9.0. Docking of sulfite reductase with the ligands was performed using iGEMDOCK and Autodock Vina softwares. The physicochemical, pharmacokinetic, drug-likeness, lead-likeness, and toxicological properties were obtained by SWISSADME and admetSAR online tools

Results: The active ingredients show an excellent affinity with the sulfite reductase which obtained was tabulated and the significant properties of a ligand were showing that these can be an investigational new drug entity.

Conclusion: In this research, it can concluded that the secondary metabolites obtained from plants were inhibiting the induction of sulfite reductase thereby inhibiting Sulfite Assimilation Pathway leads to commove the amino acid metabolism of organism which shows unique in fungi.

Keywords: Sulfite reductase, Sulfate assimilation pathway, Azadirachta indica, Lawsonia inermis, OPENBABEL, iGEMDOCK, Autodock Vina, SwissADMET, admetSAR.

(C) 2018 The Authors. Published by Innovare Academic Sciences Pvt Ltd. This is an open access article under the CC BY license (http://creativecommons. org/licenses/by/4. 0/) DOI: http://dx.doi.org/10.22159/ajpcr.2018.v11i7.26695

\section{INTRODUCTION}

Fungi are eukaryotic organisms of non-motile in nature with rigid cell wall and are around 80,000 species have been known but only about 400 species are clinically important, and about 50 are responsible for $90 \%$ of the infections of human beings, and other animals. Mycology is the branch of science which deals with the fungal organisms. Mycoses are a variety of common environmental and physiological conditions than can cause fungal diseases. Most pathogenic fungi are exogenous, their natural habitats being water, soil, and organic debris. The mycoses with the highest incidence are candidiasis and dermatophytosis which were caused by fungi. Dermatophytosis caused by fungal organisms is a ubiquitous problem and seems to be as the important cause for the morbidity [1]

The importance of medicinal plants in treating diseases is tailor-made from centuries as these contain components of therapeutic value [2]. Around 250,000 species of higher plants were estimated of their pharmacological activities and not proven completely. The antimicrobial properties of certain Indian medicinal plants were reported based on folklore information [3] and a few attempts were made on inhibitory activity against certain pathogenic bacteria and fungi [4]

Sulfite reductase is an enzyme involved in the sulfate assimilation pathway with EC no: 1.8.1.2 that influences the sulfur metabolism [5]. The sulfate assimilation pathway is not essential for the fungi as fungal organisms can utilize by the availability of methionine from environment. In the process of synthesis of cysteine and methionine in fungi requires cellular uptake and reduction of sulfate to sulfide which is an assimilatory in nature [6]. In Saccharomyces cerevisiae, the sulfate assimilation pathway is considered as a part of the methionine metabolism. Some studies show that the genes implicated in different steps of this pathway can meet their auxotrophic requirement by methionine. In yeast, no monogenic mutant has yet been found and to be a strict cysteine auxotroph. A few years ago, about 100 methionine auxotrophs have been classified in to different complementation group [6]. The sulfate assimilation pathway is the mechanism involved the interference of amino acid transport and cellular regulation of amino acid metabolism in the fungal organism [7]. Inhibition of induction of sulfite reductase enzyme of sulfate assimilation pathway was found to be the major cause of SA inhibition [8]. The inhibition of sulfite reductase may leads to repression of transcription of genes and interference of post-translational steps for expression of sulfite reductase activity [8].

Azadirachta indica is commonly called as neem which is an indigenous plant with a multitudinous uses because of medicinal properties $[9,10]$. The phytochemical compounds of $A$. indica can be alkaloids, flavonoids, triterpenoids, phenolic compounds, carotenoids, steroids, and ketones, biologically most active compound is Azadirachtin which is a mixture of seven isomeric compounds labeled as azadirachtin A-G and azadirachtin E $[11,12]$. Biologically important secondary metabolites from various parts of the plant were azadirachtin, meliacin, gedunin, nimbidin, nimbolides, salanin, nimbin, valassin, meliacin makes the bitter taste of neem oil, and the seeds contain tignic acid which is responsible for distinctive odor [13]. Neem kernels contain $30-50 \%$ of oil mainly used by the soap, pesticide, and pharmaceutical industries and also contain many active ingredients which are together called triterpene or limonoids [14]. The four best limonoid compounds are: Azadirachtin, Salannin, Meliantriol, and Nimbin. Limonoids contain insecticidal and pesticidal activity [15]. 
Lawsonia inermis is commonly called as henna which is having very potent anti-microbial properties. The phytochemical investigation of henna over the past decades led to the isolation of several important active ingredients such as b-sitosterol glucosides, flavonoids, quinoids, naphthalene derivatives, triterpenoids, coumarins, xanthones, and phenolic glycosides [16]. The isolated compounds and different henna extracts were evaluated for their antibacterial, antiviral, antimycotic, and antiparasitic activities [17]

In our continuous effort to discover a natural agent as a drug which acts as a novel potential drug target to reduce untoward effects, we selected the secondary metabolites of $A$. indica and L. inermis. These metabolites are to be tested for their potential to inhibit sulfite reductase which plays a role in amino acid metabolism of fungal organism called sulfate assimilation pathway.

\section{METHODS}

\section{Preparation of Protein by homology modeling}

Sulfite reductase is an enzyme that involves in sulfate assimilation pathway which is a vital for the metabolism of various sulfur containing metabolic reactions. The three-dimensional (3D) structure of this enzyme is not available in RCSB database. The primary structure of sulfite reductase (Uniprotkb accession no: A0A0J1ATI0) was retrieved in FASTA format from UniprotKB database [18]. The homology template of sulfite reductase (template RCSB accession code: 1MI3) was obtained from RCSB protein data bank database. The homology model was performed using MODELLAR software version 9.0 with Easy modeller as GUI. The query sequence of the sulfite reductase was aligned with the template sequence to generate 3D structure. The generated 3D structure of the protein was validated by Ramachandran plot.

\section{Preparation of ligand}

Azadirachtin, nimbin, and nimonol were the most essential secondary metabolites selected from $A$. indica and alpha-ionone, beta-ionone, lawsone, lawsoniaside, scopoletin, and stigmasterol were selected from L. inermis. These ligands were obtained from PubChem database, as SDF format. The SDF file was converted into PDB file with software OPENBABEL. The physiochemical, pharmacokinetic, toxicity, druglikeness, and lead-likeness properties of these ligands were evaluated by free web tool SwissADME [19], and admetSAR [20]

\section{Protein-ligand docking}

Initially rough docking was performed between the protein and each ligand with iGEMDOCK 2.0 with a population size of 150 and 70 generations, set as default. The protein-ligand docking was performed by Autodock Vina [21], an interactive molecular graphics program for calculating and displaying feasible docking modes of protein and ligands and were presented hierarchically based on the binding affinity. The best docked protein-ligand interaction was visualized using PyMOL [22] which is an open-source molecular visualization system.

\section{RESULTS}

\section{Homology modeling and protein validation}

The 3D structure of sulfite reductase was obtained by homology modeling and was validated by Ramachandran plot. Ramachandran plot/diagram, was developed by Ramachandran et al. [23], in 1963, is helpful to visualize energetically allowed regions for backbone [24] dihedral angles $\psi(\mathrm{psi})$ against $\varphi$ (phi) of amino acid residues in protein structure which was shown in Fig. 1. The Ramachandran plot showed that the modeled protein contains $93.3 \%$ of amino acid residues in the favored region, $5.3 \%$ in allowed region, and $1.4 \%$ in amino acid residues in disallowed region.

\section{Protein-ligand docking}

The sulfite reductase was docked with a number of small molecules known as secondary metabolites of $A$. indica and $L$. inermis. The docked poses of the sulfite reductase with all the ligands were shown in Fig. 2. The energy values, Van der Waals force (VDW), and hydrogen bond (H-bond) between protein and ligand were derived by rough docking with iGEMDOCK and Autodock Vina was presented in Table 1. The energy values obtained by sulphite reductase with compounds of $A$. indica and L. inermis was excellent, azadirachtin was -168.194 stands

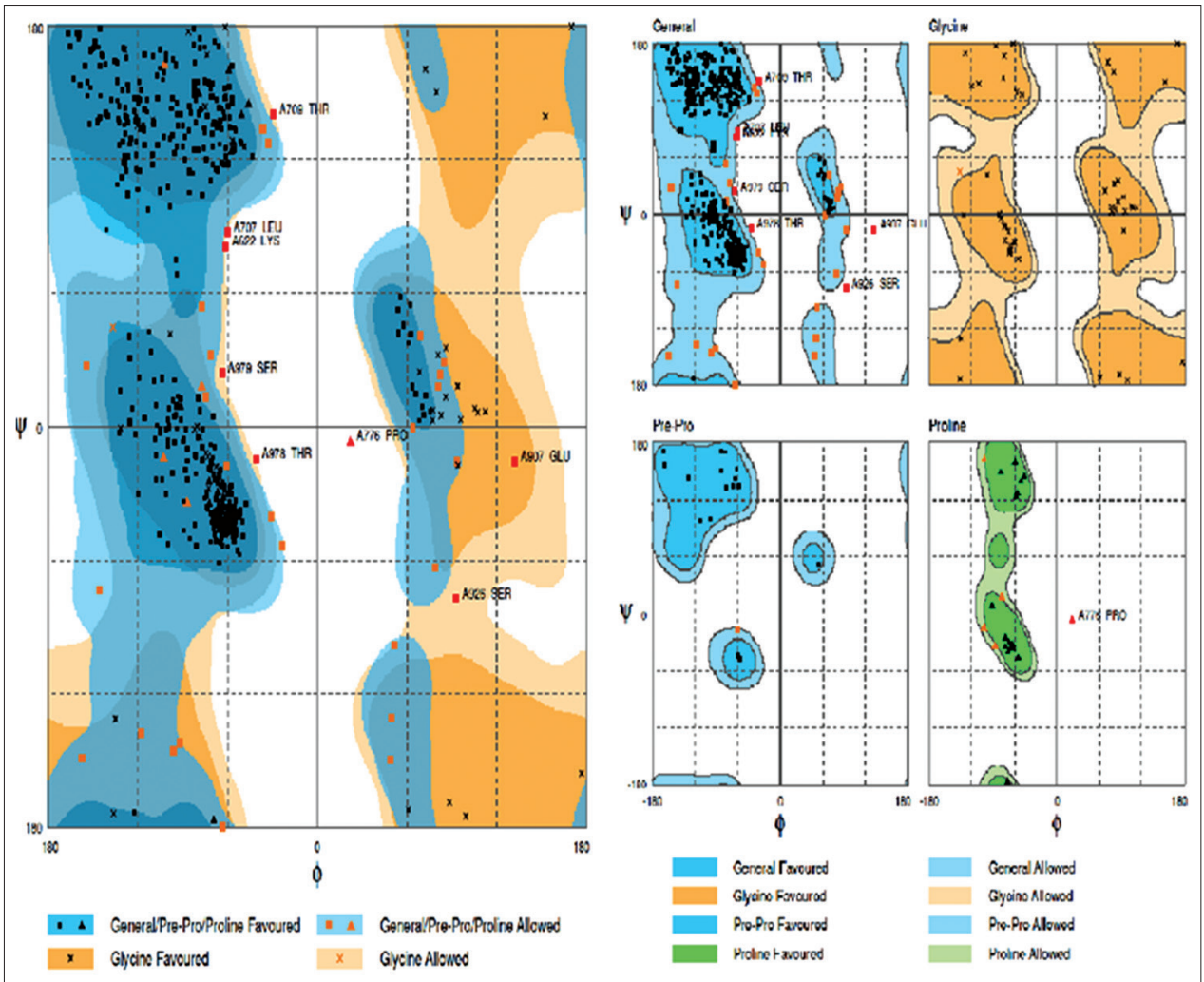

Fig. 1: Ramachandran plot shows the number of amino acids that are favored, allowed, and disallowed in model protein sulfite reductase 
maximum in $A$. indica and scopoletin as -94.5167 stands maximum in L. inermis with iGEMDOCK and -14.4 for azadirachtin in A.indica secondary metabolites and -9.7 for lawsoniaside in L. inermis secondary metabolites with Autodock Vina. The VDW between them was more for azadirachtin and alpha-ionone as -138.575 and -82.484 , respectively.

The physicochemical properties such as molecular weight, heavy atoms, Fraction Csp3, rotatable bonds, H-bond acceptors, H-bond donors, molecular refractivity, and topological polar surface area (TPSA) of all the ligands were presented in Table 2 on which the molecular weight, number of atoms, fraction Csp3, number of rotatable bonds, molar refractivity, and TPSA, for azadirachtin, nimbin, and lawsoniaside observes as these were not following the Lipinski rule of five $[25,26]$ and drug-likeliness properties as the molecular weight is more than 500. The number of atoms required for drug-likeliness [27] should be in a range of 20-70 atoms which were obeyed by all selected secondary metabolites. The hydrogen bond acceptors for azadirachtin and lawsoniaside were above 10 which states these are not following Lipinski rule. Fraction Csp3 [19] is the ratio of sp3 hybridized carbons over the total carbon count of the molecule which was not obeyed by lawsone and scopoletin as it should be at least 0.25 . Molar refractivity is more than 130 for azadirachtin and nimbin that these were not

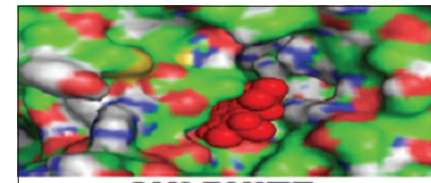

SULPHITE

REDUCTASE + AZADIRACHTIN

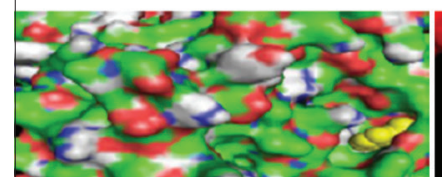

SULPHITE REDUCTASE + ALPHAIONONE

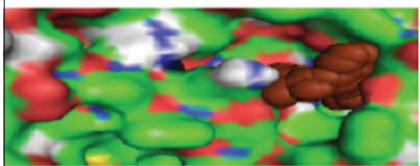

SULPHITE REDUCTASE + LAWSONIASIDE

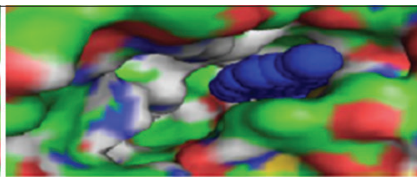

SULPHITE REDUCTASE + NIMBIN

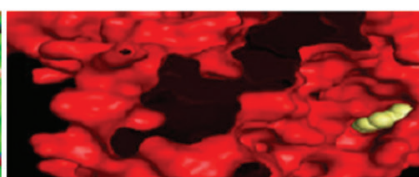

SULPHITE REDUCTASE + BETAIONONE

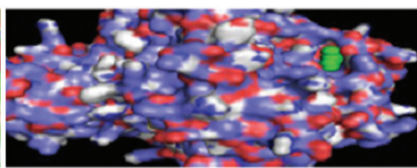

SULPHITE REDUCTASE + SCOPOLETIN

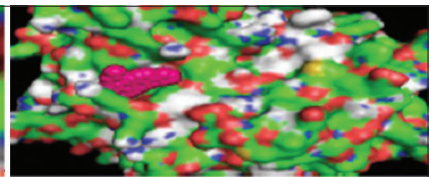

SULPHITE REDUCTASE + NIMONOL

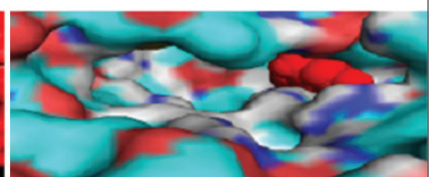

SULPHITE REDUCTASE + LAWSONE

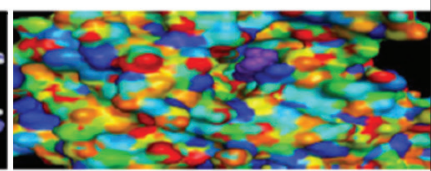

SULPHITE REDUCTASE + STIGMASTEROL

Fig. 2: The picture showing the docking poses of sulfite reductase with all ligands (secondary metabolites of Azadirachta indica and Lawsonia inermis)

Table 1: The results of rough docking and accurate docking performed with a software iGEMDOCK and Autodock Vina between the drug targets and ligands

\begin{tabular}{|c|c|c|c|c|c|c|c|c|c|}
\hline \multirow[t]{2}{*}{ S no. } & \multirow{2}{*}{$\begin{array}{l}\text { Drug targets or } \\
\text { protein with ligand }\end{array}$} & \multicolumn{5}{|c|}{ Rough docking energy values with iGEMDOCK } & \multicolumn{3}{|c|}{ Binding affinity with Autodock Vina } \\
\hline & & $\begin{array}{l}\text { Total Energy } \\
\text { Kcal/mol }\end{array}$ & VDW & H-bond & Elec & Aver Con Pair & Energy Kcal/mol & RMSD/UB & RMSD/LB \\
\hline 1 & $\begin{array}{l}\text { Sulfite reductase + } \\
\text { azadirachtin }\end{array}$ & -168.194 & -138.575 & -29.619 & 0 & 26.7647 & -14.4 & 0 & 0 \\
\hline 2 & $\begin{array}{l}\text { Sulfite reductase + } \\
\text { nimbin }\end{array}$ & -143.362 & -136.408 & -6.954 & 0 & 19.8718 & -13.4 & 0 & 0 \\
\hline 3 & $\begin{array}{l}\text { Sulfite reductase + } \\
\text { nimonol }\end{array}$ & -128.922 & -125.422 & -3.5 & 0 & 23.1212 & -13.3 & 0 & 0 \\
\hline 4 & $\begin{array}{l}\text { Sulfite reductase + } \\
\text { alpha-ionone }\end{array}$ & -84.9848 & -82.484 & -2.5 & 0 & 34.4286 & -7.1 & 0 & 0 \\
\hline 5 & $\begin{array}{l}\text { Sulfite reductase + } \\
\text { beta-ionone }\end{array}$ & -83.9837 & -80.483 & -3.5 & 0 & 33.4286 & -7.2 & 0 & 0 \\
\hline 6 & $\begin{array}{l}\text { Sulfite reductase + } \\
\text { lawsone }\end{array}$ & -90.0447 & -67.1 & -22.944 & 0 & 33.6923 & -7.8 & 0 & 0 \\
\hline 7 & $\begin{array}{l}\text { Sulfite reductase + } \\
\text { lawsoniaside }\end{array}$ & 104.201 & 128.893 & -24.692 & 0 & 18.9714 & -9.7 & 0 & 0 \\
\hline 8 & $\begin{array}{l}\text { Sulfite reductase + } \\
\text { scopoletin }\end{array}$ & -94.5167 & -74.858 & -19.658 & 0 & 33.5714 & -7.2 & 0 & 0 \\
\hline 9 & $\begin{array}{l}\text { Sulfite reductase + } \\
\text { stigmasterol }\end{array}$ & -39.2956 & -39.295 & 0 & 0 & 10.8 & -8.9 & 0 & 0 \\
\hline
\end{tabular}

VDW: Van der Waals force, H-bond: Hydrogen bond, RMSD: Root mean square deviation 


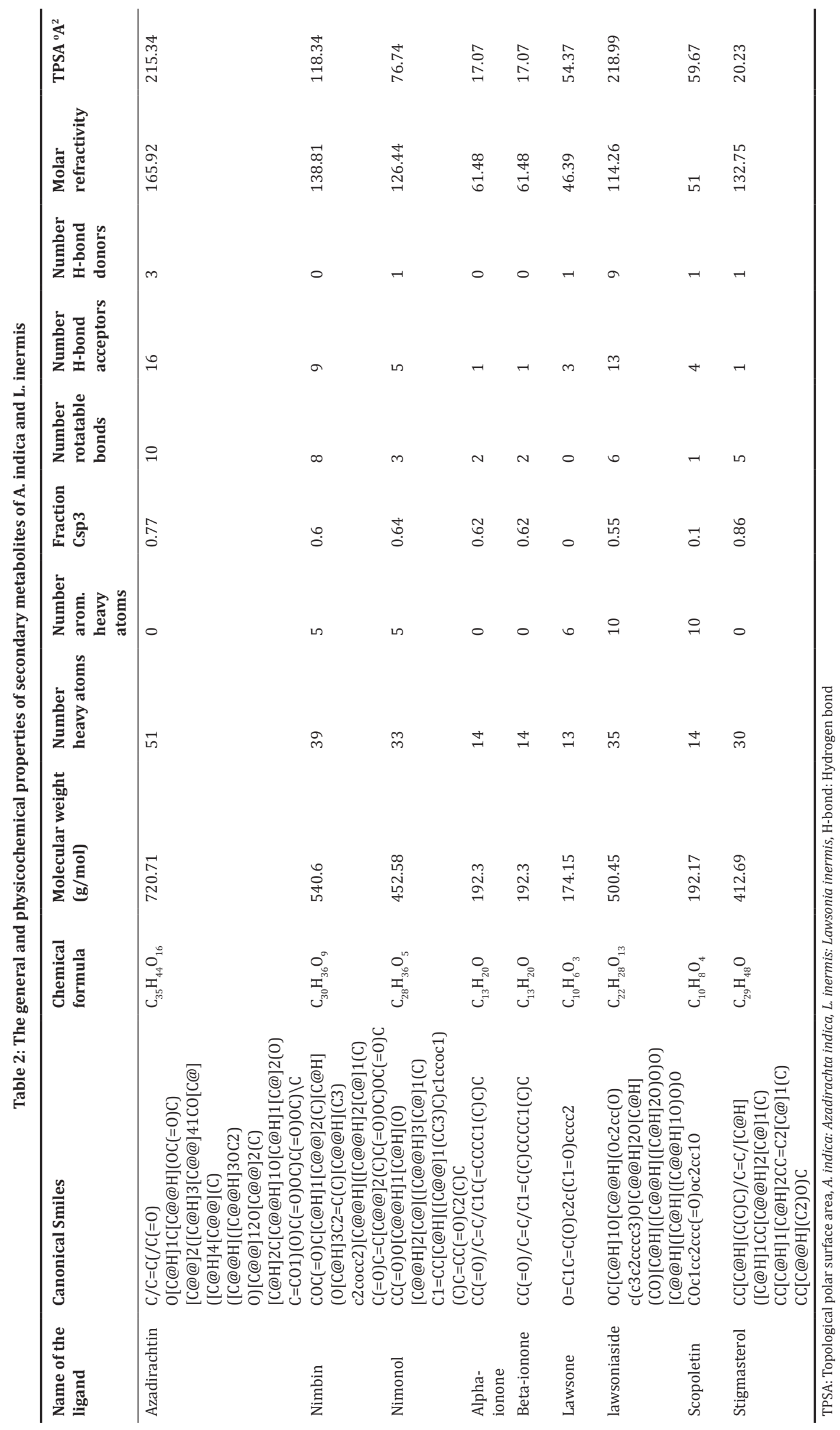


following drug-likeliness. The TPSA is also more than 140 angstroms squared for azadirachtin and lawsoniaside which tends to be likely poor permeability between cells [28]. The nimonol, alpha-ionone, betaionone, lawsone, scopoletin, and stigmasterol TPSA are $<90$ angstroms squared depicts as penetratable the blood brain barrier (BBB) [29].

Table 3 presents the pharmacokinetic property of secondary metabolites of $A$. indica and L. inermis, implies as alpha-ionone is more hydrophilic with -1.7995 and nimbin, stigmasterol, and nimonol are less aqueous soluble with $-4.4552,-4.7027$, and -5.0718 respectively. As the cell permeability is proportional to Caco-2 results, the lawsoniside is less permeable and alpha-ionone was more permeable. Alpha-ionone, betaionone, and stigmasterol were localized to lysosomes and others were to mitochondria. The azadirachtin, lawsoniaside, and stigmasterol were poorly absorbs through gastrointestinal system. Alpha-ionone, beta-ionone, lawsone, and scopoletin show permeability to BBB. The azadirachtin and nimonol were the substrates for efflux pump called P-glycoprotein. All the ligands were not influencing cytochrome P450 (CYP) isoenzymes which predict as null drug interactions and no alteration in titration of dose except scopoletin which inhibits CYP4501A2. All the ligands have an excellent permeability through skin.

Table 4 describes the drug-likeliness and lead-likeliness of secondary metabolites of $A$. indica and $L$. inermis. The nimonol, alpha-ionone, betaionone, lawsone, and scopoletin follows the Lipinski's rule of 5 as well as Ghose rule [27] and others were violating. Veber rule [30] states as rotatable bonds need to be $\leq 10$ and TPSA need to be $\leq 140$ was followed by all ligands except azadirachtin and lawsoniaside. Egan's filter [31] was followed by all except azadirachtin, lawsoniaside, and stigmasterol. Most of the compounds don't obey the Muegge's filter [32] except nimbin and nimonol. The bioavailability score [33] for these ligands were good as these ligands' probability for a new drug was at least $10 \%$ oral bioavailability in rodents. The lead-likeliness for these ligands was followed for pains filter [34] except for lawsone, 3 violations were observed for Brenk filter [35] and for lead-likeness there was 1 violation for beta-ionone, lawsone, lawsoniaside, and scopoletin, and others were 2 violations. The synthetic accessibility was very difficult for azadirachtin being 8.1 and very easy for lawsone being 2.46 followed by scopoletin.

Table 5 depicts the toxicity profile of the secondary metabolites of $A$. indica and $L$. inermis which can be assumed as non-toxic as these were negative for cardiotoxicity as these does not cause an efflux of potassium by human ether-a-go-go-related gene protein blockade. Negative in AMES mutagenicity test portrayed as negative teratogenicity, fetotoxicity, and fetal malformations. All the compounds were categorized as non-carcinogens, and acute oral toxicity was stated as Category I, i.e., lethal dose 50 value is $\leq 50 \mathrm{mg} / \mathrm{kg}$. The rat acute toxicity was also in the lower limits for all the ligands.

\section{DISCUSSION}

The infections caused by the fungal organisms become a threat and challenging to the medical fraternity as they are increasing day by day due to opportunistic infections and invasive systemic infections. It is the time to expose for a new drug target and new drugs to inhibit the growth of fungi. In this study, we selected sulfite reductase as a new drug target and the secondary metabolites as drugs which hamper the activity of the enzyme to impair the metabolic function of fungi. A study by Aoki et al. [36] observed that azoxybacillin, isolated by $B$. Cereus with broad spectrum of antifungal activity by interfering with the regulation of expression of sulfite reductase activity. In another study by Jorge Amich et al. [37], methionine synthase which is a part of sulfur assimilation pathway is essential for A. fumigatus virulence observes as the biosynthetic route for the proteinogenic amino acid as a potential antifungal target to inhibit the growth. In research by Mendoza-Cózatl et al. [38], sulfate assimilation reduction and GSH metabolism were regulated with cadmium intoxication of yeast, plants, and protists. In a study by Mondall et al. [39], alcoholic extract of 6-7-day-old leaf of neem shows more activity than aqueous,

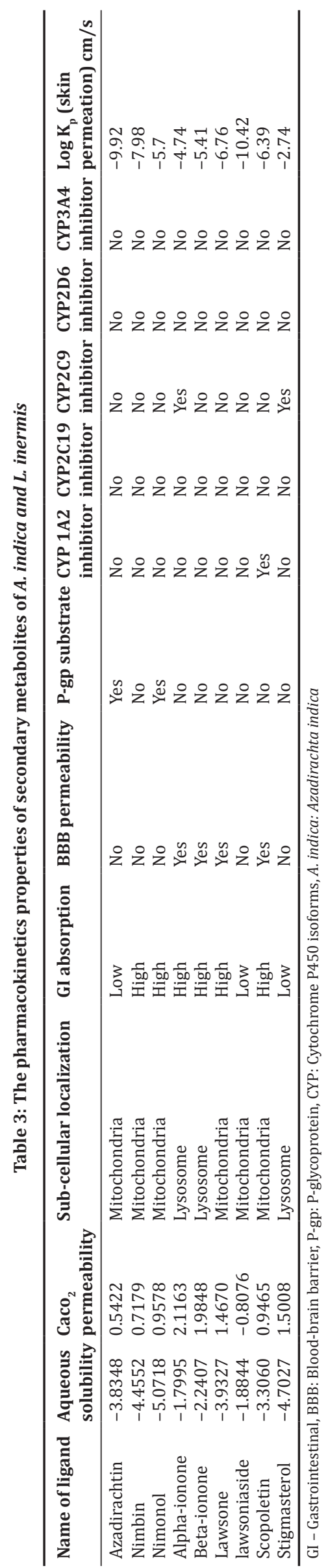


Table 4: The drug-likeliness and lead-likeliness of secondary metabolites of $A$. indica and $L$. inermis

\begin{tabular}{|c|c|c|c|c|c|c|c|c|c|c|}
\hline \multirow{2}{*}{$\begin{array}{l}\text { Name of the } \\
\text { ligand }\end{array}$} & \multicolumn{6}{|c|}{ Drug-likeliness } & \multicolumn{4}{|c|}{ Lead-likeliness } \\
\hline & Lipinski & Ghose & Veber & Egan & Muegge & Bioavailability score & Pains & Brenk & Lead-likeness & $\begin{array}{l}\text { Synthetic } \\
\text { Accessibility }\end{array}$ \\
\hline Azadirachtin & 2 & 3 & 1 & 1 & 4 & 0.17 & 0 & 3 & 2 & 8.11 \\
\hline Nimbin & 1 & 3 & 0 & 0 & 0 & 0.55 & 0 & 2 & 2 & 6.54 \\
\hline Nimonol & 0 & 0 & 0 & 0 & 0 & 0.55 & 0 & 1 & 2 & 6.04 \\
\hline Alpha-ionone & 0 & 0 & 0 & 0 & 2 & 0.55 & 0 & 2 & 2 & 3.53 \\
\hline Beta-ionone & 0 & 0 & 0 & 0 & 2 & 0.55 & 0 & 1 & 1 & 3.38 \\
\hline Lawsone & 0 & 1 & 0 & 0 & 1 & 0.56 & 2 & 1 & 1 & 2.46 \\
\hline Lawsoniaside & 3 & 2 & 1 & 1 & 3 & 0.17 & 0 & 0 & 1 & 5.76 \\
\hline Scopoletin & 0 & 0 & 0 & 0 & 1 & 0.55 & 0 & 1 & 1 & 2.62 \\
\hline Stigmasterol & 1 & 3 & 0 & 1 & 2 & 0.55 & 0 & 1 & 2 & 6.21 \\
\hline
\end{tabular}

A. indica: Azadirachta indica, L. inermis: Lawsonia inermis

Table 5: The toxicity profile of secondary metabolites of $A$. indica and $L$. inermis

\begin{tabular}{llllll}
\hline Name of ligand & hERG inhibition & AMES toxicity & Carcinogens & Acute oral toxicity & Rat acute toxicity (LD 50) mol/kg \\
\hline Azadirachtin & 0.9919 & 0.7563 & 0.9455 & 0.6952 & 4.3477 \\
Nimbin & 0.9755 & 0.9132 & 0.9131 & 0.77 & 2.922 \\
Nimonol & 0.9707 & 0.9315 & 0.9231 & 0.5415 & 2.9784 \\
Alpha-ionone & 0.9202 & 0.9400 & 0.6772 & 0.8297 & 1.6526 \\
Beta-ionone & 0.8862 & 0.9132 & 0.6926 & 0.7883 & 1.6532 \\
Lawsone & 0.9541 & 0.9107 & 0.9077 & 0.4042 & 3.0215 \\
Lawsoniaside & 0.9276 & 0.6101 & 0.9615 & 0.4360 & 1.9523 \\
Scopoletin & 0.9672 & 0.5514 & 0.9518 & 0.8059 & 2.6022 \\
Stigmasterol & 0.8027 & 0.9132 & 0.9182 & 0.4287 & 2.6561 \\
\hline
\end{tabular}

hERG: Human ether-a-go-go-related gene, LD: Lethal dose, A. indica: Azadirachta indica, L. inermis: Lawsonia inermis

and the triterpenoids [40] such as azadirachtin, nimbin, and nimonol are the ingredients that show fungicidal activity. According to Dubey and Kumar [41], azadirachtin shows an excellent fungicidal action as it possesses equally as mancozeb and bavistin. In a study conducted by Mahmoud et al. [42], aqueous and organic extracts of neem leaves showed their inhibitory effect against the pathogenic fungi. In this same study, the mixture of fractions eluted by high-performance liquid chromatography was more effective than the pure nimonol may be because combination exhibits synergism. According to Suleiman and Mohamed [43], ethanol and petroleum ether extracts of L. inermis (Henna) revealed antifungal activity against superficial and systemic infections. A research by Sharma et al. [44] reported that the sensitivity of dermatophytes with henna was robust in Trichophyton mentagrophytes, Trichophyton rubrum, Trichophyton tonsurans, Trichophyton violaceum, Trichophyton verrucosum, Trichophyton schoenleinii, Epidermophyton floccosum, Microsporum ferrugineum, Microsporum canis, and Sporotrichum schenckii. A study by Raveesha et al. [45] showed that aqueous extract of L. inermis and 10 more other plants has observed significant antifungal activity against Aspergillus species. Another research by Amal Nawasrah et al. [46] showed that addition of henna extract to acrylic resin denture shows the inhibition of the growth of Candida albicans in dentures. This study shows that sulfite reductase inhibition shackles the sulfate assimilation pathway which is essential for fungal survival with the secondary metabolites of A. indica and L. inermis.

\section{CONCLUSION}

Inhibition of sulfite reductase enzyme of sulfate assimilation pathway with the help of small molecules of secondary metabolites of certain plants such as $A$. indica and L. inermis may lead to repression of certain genes of sulfite reductase activity and post-translational steps of expression of sulfite reductase which can be a new drug target and the secondary metabolites can be an investigational new drugs.

\section{ACKNOWLEDGMENTS}

We are very thankful to Dr. P. Thirugnanasambantham and Dr. K. Jayachandra of Rumi Herbals Pvt., Ltd., for giving the extensive support and management of Tagore Medical College and Hospital for providing facility to do my research.

\section{AUTHOR'S CONTRIBUTION}

1. Simhadri.V.S.D.N.A.Nagesh - Principal Investigator

2. Dr. M. Muniappan - Guide

3. Dr. I. Kannan - CoGuide

4. Dr. S.Viswanathan - Provided required software for study.

\section{CONFLICTS OF INTEREST}

The authors have none to declare.

\section{SOURCE OF SUPPORT}

Nil.

\section{REFERENCES}

1. Borgers M, Degreef H, Cauwenbergh G. Fungal infections of the skin: Infection process and antimycotic therapy. Curr Drug Targets 2005;6:849-62.

2. Nostro A, Germano MP, Amgelo VA, Marino A, Cannatelli MA. Extraction methods and bioautography for evolution of medicinal plant antimicrobial activity. Lett Appl Microbiol 2000;30:379-88.

3. Murthy Ks, Lakshmi N, Ramulu DR. Biological activity and phytochemical screening of the oleoresin of Shorea robusta Gaertn. f. Trop Subtrop Agroecosys 2011;14:787-91.

4. Taylor RS, Manandhar NP, Towers GH. Screening of selected medicinal plants of Nepal for antimicrobial activities. J Ethnopharmacol 1995;46:153-9.

5. Parey K, Warkentin E, Kroneck PM, Ermler U. Reaction cycle of the dissimilatory sulfite reductase from Archaeoglobus fulgidus. 
Biochemistry 2010;49:8912-21.

6. Thomas d, Barbey r, Surdin-Kerjan Y. Gene-enzyme relationship in the sulfate assimilation pathway of Saccharomyces cerevisiae. J Biol Chem 1990;265:15518-24.

7. Mazu TK, Bricker BA, Flores-Rozas H, Ablordeppey SY. The mechanistic targets of antifungal agents: An overview. Mini Rev Med Chem 2016;16:555-78

8. Sundriyal S, Sharma RK, Jain R. Current advances in antifungal targets and drug development. Curr Med Chem 2006;13:1321-35.

9. Mosaddek AS, Rashid MM. Comparative study of the anti-inflammatory effect of aqueous extract of neem leaf and dexamethasone. Bangl J Pharmacol 2008:3:44-7.

10. Patil PR, Patil SP, Mane A, Verma S. Antidiabetic activity of alcoholic extract of Neem (Azadirachta indica) root bark. Natl J Physiol Pharm Pharmacol 2013;3:142-6

11. Verkerk RH, Wright DJ. Biological activity of neem seed kernel extract and synthetic azadirachtin against larvae of Plutella xylostellal. Pesticide Sci 1993;37:83-91.

12. Hashmat I, Azad H, Ahmed A. Neem (Azadirachta indica A. Juss)-a nature's drugstore: An overview. Int Res J Biol Sci 2012;1:76-9.

13. Sharma P, Tomar L, Bachwani M, Bansal V. Review on neem (Azadirechta indica): Thousand problem one solution. Int Res J Pharm 2011;2:97-102.

14. Tindo SD, Tamal M. Screening of repellent, termiticidal and preventive activities on wood, of Azadirachta indica and Carapa procera (Meliaceae) seeds oils. ISCA J Biol Sci 2012;1:25-9.

15. Mondal D, Mondal T. A review on efficacy of Azadirachta indica A. Juss based biopesticides: An Indian perspective. Res J Recent Sci 2012;1:94-9.

16. Ahmed S, Rahman A, Alam A, Saleem M, Athar M, Sultana S. Evaluation of the efficacy of Lawsonia alba in the alleviation of carbon tetrachlorideinduced oxidative stress. J Ethnopharmacol 2000;69:157-64.

17. Babu PD, Subhasree RS. Antimicrobial activities of Lawsonia inermis - a review. Acad J Plant Sci 2009;2:231-2.

18. Putra AM, Chaidir C, Hanafi M, Yanuar A. Predicted binding mode of andrographolide and its derivatives bound to Plasmodium falciparum geranylgeranyl pyrophosphate synthase. Int J App Pharm 2017;9(1 Suppl):94-7.

19. Daina A, Michielin O, Zoete V. SwissADME: A free web tool to evaluate pharmacokinetics, drug-likeness and medicinal chemistry friendliness of small molecules. Sci Rep 2017;7:42717.

20. Cheng F, Li W, Zhou Y, Shen J, Wu Z, Liu G, et al. AdmetSAR: A comprehensive source and free tool for assessment of chemical ADMET properties. J Chem Inf Model 2012;52:3099-105.

21. Trott $\mathrm{O}$, Olson AJ. Auto dock vina: Improving the speed and accuracy of docking with a new scoring function, efficient optimization and multithreading. J Comput Chem 2010;31:455-61.

22. Yanuar A, Syahdi RR, Aryati WD. Parameter optimization and virtual screening indonesian herbal database as human immunodeficiency virus-1 integrase inhibitor using autodock and vina. Int J App Pharm 2017;9(1 Suppl):90-3.

23. Ramachandran GN, Ramakrishnan C, Sasisekharan V. Stereiochemistry of polypeptide chain configurations. J Mol Biol 1963;7:95-9.

24. Richardson JS. Anatomy and taxonomy of protein structures. Adv Protein Chem 1981;34:167-39.

25. Lipinski CA, Lombardo F, Dominy BW, Feeney PJ. Experimental and computational approaches to estimate solubility and permeability in drug discovery and development settings. Adv Drug Deliv Rev 2001;46:3-26.

26. Lipinski CA. Lead and druglike compounds: the rule of five revolution.
Drug Discov Today Technol 2004;1:337-41.

27. Ghose AK, Viswanadhan VN, Wendoloski JJ. A knowledge-based approach in designing combinatorial or medicinal chemistry libraries for drug discovery. 1. A qualitative and quantitative characterization of known drug databases. J Comb Chem 1999;1:55-8.

28. Pajouhesh H, Lenz GR. Medicinal chemical properties of successful central nervous system drugs. Neuro Rx 2005;2:541-53.

29. Hitchcock SA, Pennington LD. Structure-brain exposure relationships. J Med Chem 2006;49:7559-83.

30. Veber DF, Johnson SR, Cheng HY, Smith BR, Ward KW, Kopple KD, et al. Molecular properties that influence the oral bioavailability of drug candidates. J Med Chem 2002;45:2615-23.

31. Egan WJ, Merz KM, Baldwin JJ. Prediction of drug absorption using multivariate statistics. J Med Chem 2000;43:3867-77.

32. Muegge I, Heald SL, Brittelli D. Simple selection criteria for drug-like chemical matter. J Med Chem 2001;44:1841-6.

33. Martin YC. A bioavailability score. J Med Chem 2005;48:3164-70.

34. Baell JB, Holloway GA. New substructure filters for removal of pan assay interference compounds (PAINS) from screening libraries and for their exclusion in bioassays. J Med Chem 2010;53:2719-40.

35. Brenk R, Schipani A, James D, Krasowski A, Gilbert IH, Frearson J, et al. Lessons learnt from assembling screening libraries for drug discovery for neglected diseases. ChemMedChem 2008;3:435-44.

36. Aoki Y, Yamamoto M, Hosseini-Mazinani SM, Koshikawa N, Sugimoto K, Arisawa M. Antifungal azoxybacilin exhibits activity by inhibiting gene expression of sulfite reductase. Antimicrob Agents Chemother 1996;40:127-32.

37. Amich J, Dümig M, O'Keeffe G, Binder J, Doyle S, Beilhack A, et al. Exploration of sulfur assimilation of Aspergillus fumigatus reveals biosynthesis of sulfur-containing amino acids as a virulence determinant. Infect Immun 2016;84:917-29.

38. Mendoza-Cózatl D, Loza-Tavera H, Hernández-Navarro A, MorenoSánchez R. Sulfur assimilation and glutathione metabolism under cadmium stress in yeast, protists and plants. FEMS Microbiol Rev 2005;29:653-71.

39. Mondall NK, Mojumdar A, Chatterje SK, Banerjee A, Datta JK, Gupta S. Antifungal activities and chemical characterization of Neem leaf extracts on the growth of some selected fungal species in vitro culture medium. J Appl Sci Environ Manage 2009;13:49-3.

40. Brahmachari G. Neem-an omnipotent plant: A retrospection. Chem Bio Chem 2004;5:408-21.

41. Dubey RC, Kumar R. Efficacy of azadirachtin and fungicides on growth and survival of sclerotia of Macrophomina phaseolina causing charcoal rot of soybean. Indian Phytopath 2003;56:216-7.

42. Mahmoud DA, Hassanein NM, Youssef KA, Zeid MA. Antifungal activity of different neem leaf extracts and the nimonol against some important human pathogens. Braz J Microbiol 2011;42:1007-16.

43. Suleiman EA, Mohamed EA. In vitro activity of Lawsonia inermis (Henna) on some pathogenic fungi. J Mycol 2014. Article ID: 375932, 5 Pages.

44. Sharma KK, Saikia R, Kotoky K, Kalita JC, Devi R. Antifungal activity of Solanum melongena L, Lawsonia inermis L. and Justicia gendarussa B against dermatophytes. Int J Pharm Technol Res 2011;3:1635-40

45. Raveesha KA, Satish S, Mohana DC, Raghavendra MP. Antifungal activity of some plant extracts against important seed borne pathogens of Aspergillus spp. J Agric Technol 2007;3:109-19.

46. Nawasrah A, AlNimr A, Ali AA. Antifungal effect of henna against Candida albicans adhered to acrylic resin as a possible method for prevention of denture stomatitis. Int J Environ Res Public Health 2016;13:520. 